\title{
Análise linguística a partir de memes: uma proposta de ensino
}

Lia Simões Nery ${ }^{\mathrm{i}}$

\section{RESUMO}

Este artigo tem por objetivo discutir a experiência de uma proposta de ensino com análise linguística e memes aplicada no Colégio Estadual Odorico Tavares, com estudantes do ensino médio, durante o período de Estágio Supervisionado II de Língua Portuguesa, realizado no curso de Letras da Universidade Federal da Bahia, no ano de 2019. Trata-se de uma pesquisa-ação educacional (TRIPP, 2005), a qual foi realizada com as etapas de planejamento, aplicação da proposta, monitoramento e avaliação dos resultados, a fim de investigar o processo de análise linguística (GERALDI, 2002) a partir de memes, para promover transformações necessárias no que se refere à compreensão e reflexão da língua em um gênero discursivo digital (BAKHTIN, 2003). Nesse sentido, os resultados da proposta evidenciaram a importância do ensino com os gêneros digitais nas aulas de língua portuguesa, para desenvolver leitores críticos (ROJO, 2016), ativos, capazes de refletir sobre sua própria língua e interpretar a multiplicidade de sentidos dos textos multissemióticos (SOARES, 2002).

Palavras-chave: Memes; Ensino; Língua Portuguesa; Gêneros digitais.

\begin{abstract}
This article aims to discuss the experience of a teaching proposal with linguistic analysis and memes applied at Colégio Estadual Odorico Tavares with high school students during the period of Supervised Internship II in Portuguese Language, carried out in the Letras course of the Federal University of Bahia, in 2019. This is an educational action research (TRIPP, 2005), which was carried out with the stages of planning, application of the proposal, monitoring and evaluation of the results, in order to investigate the process of linguistic analysis (GERALDI, 2002) based on memes, to promote necessary transformations regarding the understanding and reflection of the language in a digital discursive genre (BAKHTIN, 2003). In that sense, the results of the proposal showed the importance of teaching assisted by digital genres in Portuguese language classes, to develop critical, active readers (ROJO, 2016), who are able to reflect on their own language and to interpret the multiplicity of meanings of multisemiotic texts. (SOARES, 2002).
\end{abstract}

Keywords: Memes; Teaching; Portuguese Language; Digital Genres.

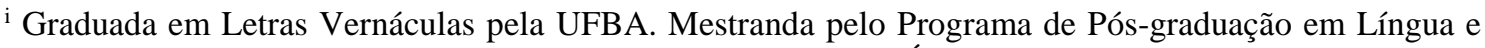
Cultura da Universidade Federal da Bahia (PPGLinc/UFBA). É participante do Grupo de Estudos em Semântica Cognitiva (GESCOG), sob coordenação da Prof. Dra. Ariadne Domingues Almeida. Desenvolve pesquisas na área da Linguística Cognitiva. Tem se dedicado recentemente aos estudos em Semântica Cognitiva, com foco em metáforas, metonímias, frames e esquemas imagéticos presentes em memes. | lias.nery@hotmail.com | https://orcid.org/0000-0003-4627-9409
} 


\section{INTRODUÇÃO}

Esta pesquisa partiu de uma inquietação inicial sobre a relação entre a educação, a língua portuguesa e a tecnologia. Contemporaneamente, temos presenciado a dificuldade relatada por muitos docentes no que se refere à preocupação em relação às atividades de leitura e produção de textos, que na opinião de alguns foram deixadas à margem diante do surgimento dos smartphones. Para esses docentes, então, o ensino de língua portuguesa tornou-se mais dificultoso, visto que os alunos não leem nem praticam mais a escrita, concentrando-se apenas em seus celulares e no universo das redes sociais.

É inegável que os avanços tecnológicos e, consequentemente, o surgimento de novos aparelhos, com acesso instantâneo à internet, modificaram as formas de estudar, ler e produzir textos. A educação foi diretamente afetada pela tecnologia. Contudo, será que os alunos estão, realmente, menos interessados, menos leitores e menos produtores com o advento das redes sociais, ou será que falta a eles um ensino que lhes possibilite o exercício das habilidades que vêm adquirindo na era das mídias sociais digitais? Será que os docentes também não necessitam revisitar as suas práticas, reformulá-las, olhar para a potencialidade do que a internet e a tecnologia têm oferecido e uni-las aos respectivos conteúdos de língua portuguesa? Esta investigação foi motivada pela busca por respostas para essas indagações.

Buscamos com esta pesquisa ratificar a importância de construir um ensino que tenha por base a realidade do aluno, a qual está marcada pelo universo da internet e das redes sociais. Assim, pretende-se discutir a importância de se trabalhar com o gênero discursivo digital meme em sala de aula, a fim de estimular no aluno um olhar crítico diante dos textos que circulam na internet, bem como para promover uma aprendizagem prazerosa, visto que é constituída a partir de gêneros próximos à sua experiência.

Dessa forma, este estudo foi elaborado a partir de uma proposta de ensino de conteúdo exclusivamente com memes aplicada no período de Estágio Supervisionado II em Língua Portuguesa, realizado em 2019. Nesse sentido, discutiremos como o ensino com memes se realizou em uma turma do terceiro ano do Ensino Médio, trazendo à baila os feedbacks das aulas, os comentários dos estudantes, as dificuldades enfrentadas por eles, 
mas também o que revelou o resultado da proposta de ensino na disciplina língua portuguesa.

Para empreendermos essa discussão, apresentamos, na primeira seção, uma breve provocação sobre o impacto da cibercultura nas relações sociais e o surgimento dos gêneros digitais; na segunda seção, explicamos o que compreendemos por análise linguística e sua inter-relação com os memes; na terceira seção, descrevemos o percurso metodológico trilhado; na quarta seção, apresentamos a discussão da aplicação da proposta de análise linguística a partir de memes nas aulas de Língua portuguesa ministradas no Colégio Estadual Odorico Tavares, com estudantes de ensino médio, durante o período do Estágio Supervisionado II. Em suma, na quinta seção, expressamos com as considerações finais e os resultados da pesquisa, seguidas das referências.

\section{NOVAS TECNOLOGIAS, NOVAS RELAÇÕES, NOVOS GÊNEROS DISCURSIVOS}

O ciberespaço, definido por Levy como "o novo meio de comunicação que surge da interconexão mundial dos computadores", e a cibercultura, um "conjunto de técnicas (materiais e intelectuais), de práticas, de atitudes, de modos de pensamento e de valores que se desenvolvem juntamente com o crescimento do ciberespaço" (LEVY, 1999, p. 18) modificaram sobremaneira as relações dos indivíduos com a leitura e a escrita. Passou-se de uma cultura do papel para a cultura da tela, e essa mudança provocou e tem provocado inúmeros "efeitos sociais, cognitivos e discursivos, resultando em modalidades diferentes de letramento, o que sugere que a palavra seja pluralizada: há letramentos, não letramento" (SOARES, 2002, p. 143).

Nesse sentido, pode-se reconhecer que está ocorrendo um processo de letramento digital e de outros letramentos ainda desconhecidos. O espaço da escrita, hoje, migrou para a tela do computador, notebook ou smartphone, o que provocou o surgimento de novas práticas de leitura e escrita. Ao entrar em contato com a tela, o indivíduo possui um leque de opções ao lidar com os textos: abrir, fechar, ampliar, acessar outros textos, destacar, compartilhar, mover. Essas ações possibilitaram o surgimento dos chamados hipertextos, os quais são uma rede infinita de possibilidades. Como evidencia Soares: 
O texto no papel é escrito e é lido linearmente, sequencialmente - da esquerda para a direita, de cima para baixo, uma página após a outra; o texto na tela - o hipertexto - é escrito e é lido de forma multilinear, multisequencial, acionando-se links ou nós que vão trazendo telas numa multiplicidade de possibilidades, sem que haja uma ordem predefinida. (2002, p. 150)

Assim, o universo digital tem promovido mudanças na relação dos indivíduos com o conhecimento (LEVY, 1999), e isso não pode deixar de ser observado na forma como os alunos escrevem, leem e se comunicam atualmente. Observa-se com frequência como os discentes retroalimentam mídias sociais diversas, utilizando-as para entretenimento, leitura de textos e para se expressarem enquanto sujeitos. De um lado, têm deixado à margem a caneta e o papel; do outro, têm aproveitado tudo que a tecnologia lhes oferece para produzir, ler, pesquisar e se comunicar de forma instantânea.

Diante dessas mudanças, novos gêneros discursivos também vêm surgindo a partir do universo digital, e torna-se cada vez mais comum a fusão de semioses distintas, como imagem, texto verbal, som, movimento etc. Como exemplos desses gêneros podemos citar o meme, o gif, o tweet, o podcast, a mensagem de áudio gravada, a postagem compartilhada, dentre outros, que têm surgido nos ambientes virtuais. Nesse processo,

\begin{abstract}
Não são somente novos gêneros que surgem ou se transformam (como post, tweet, meme, mashup, playlist comentada, reportagem multimidiática, relato multimidiático, vlog, videominuto, political remix, tutoriais em vídeo, entre outros), mas novas ações, procedimentos e atividades (curtir, comentar, redistribuir, compartilhar, taguear, seguir/ ser seguido, remidiar, remixar, curar, colecionar/descolecionar, colaborar etc.) que supõem o desenvolvimento de outras habilidades. (BRASIL, 2018, p. 479)
\end{abstract}

Devido a isso, os professores necessitam articular suas aulas a esses novos textos, para que possam propor debates, reflexões críticas, sobre os discursos que circulam nas redes sociais digitais, bem como a fim de levar o aluno a desenvolver a interpretação de textos multissemióticos e a reflexão da língua em uso. Dessa forma, os gêneros digitais devem ser aliados do ensino, sobretudo de língua portuguesa. Como afirma Lemke, é urgente a necessidade de os docentes articularem suas práticas à cultura digital:

Devemos ajudar os alunos a compreenderem exatamente como ler o texto de forma diferente e interpretar a imagem de forma diferente, em função da presença um do outro. Nós precisamos até mesmo compreender como é que 
sabemos qual texto é relevante para a interpretação de qual imagem e viceversa. Tudo isto requer, ao menos para professores e especialistas da mídia, uma compreensão útil de semiótica multimidiática. (LEMKE, 2010, p. 462)

Assim, os docentes de língua portuguesa não podem se omitir de ensinar a língua desvinculada do aspecto social, este que vem sido marcado, permanentemente, pelo digital.

Por isso, é de fundamental importância que o professor conheça os gêneros digitais e planeje ações e atividades a partir das práticas sociais de leitura e escrita do meio virtual. Essa postura deve estar presente tanto no Ensino Fundamental, quanto no Ensino Médio, pois o trabalho com gêneros digitais proporciona ao aluno o desenvolvimento de competências e habilidades interpretativas e reflexivas, além do conhecimento das mídias digitais e do vínculo com temas de relevância social que circulam por meio desses textos.

Essa necessidade vem sendo preconizada e reconhecida, inclusive, pela Base Nacional Comum Curricular:

[...] é importante que os jovens, ao explorarem as possibilidades expressivas das diversas linguagens, possam realizar reflexões que envolvam o exercício de análise de elementos discursivos, composicionais e formais de enunciados nas diferentes semioses, - visuais (imagens estáticas ou em movimento, sonoras (músicas, ruídos sonoridades), - verbais (oral, visual-motora, como Libras, e escrita), - e tecnologias da informação e da comunicação (TDIC). Afinal, muito por efeito das novas tecnologias da informação e da comunicação (TDIC), os textos e discursos atuais organizam-se de maneira híbrida e multissemiótica, incorporando diferentes sistemas de signos em sua constituição. (BRASIL, 2018, p. 476)

No que diz respeito ao ensino da língua portuguesa, as possibilidades de trabalho são múltiplas e podem ser feitas através da análise linguística, uma vez que por meio desses textos descobrem-se discursos que necessitam ser abordados em sala para serem combatidos, tais como racismo, machismo, violência de gênero, dentre outros. Além disso, questões que dizem respeito à língua surgem no processo de análise linguística, por exemplo, o efeito de sentido de um substantivo ou de um adjetivo para a construção do texto, a utilização de determinadas cores, a expressão facial de pessoas que aparecem no texto, as escolhas lexicais, a construção das frases etc. Observando todos esses aspectos, o aluno poderá revisar conteúdos de língua portuguesa, como classes de palavra, bem como desenvolverá a criticidade, interpretação e compreensão de múltiplas linguagens. Portanto, 
Ler memes pode viabilizar a implementação de práticas pautadas no caráter dialógico da linguagem e, consequentemente, problematizar questões ligadas à dimensão social e histórica, transformando a leitura em uma atividade constitutiva de sujeitos capazes de estabelecer relações com o mundo e nele atuar como cidadãos. (FERREIRA; VILLART-NEDER; COE, 2019, p. 131)

Logo, por meio desse processo os estudantes tornam-se leitores críticos (ROJO, 2016), assim, têm a oportunidade de refletir sobre as práticas de linguagem em uso, sobre os discursos, os recursos semióticos e as questões sócio-histórico-políticoideológicas que circulam na sociedade (KNOBEL; LANKSHEAR, 2020).

\section{ENTRELAÇAMENTOS DE UM ENSINO PRODUTIVO DA LÍNGUA: ANÁLISE LINGUÍSTICA E MEMES}

Ao elaborar esta proposta para ser aplicada em sala de aula, partimos de uma concepção de ensino que vê a língua(gem) como interação, a qual parte da relação entre os sujeitos, considerando-a para além de transmissão de informações, mas como uma prática na qual "o falante age sobre o ouvinte, constituindo compromissos e vínculos que não preexistem à fala" (GERALDI, 2002, p. 41). Portanto, nos pautamos no ensino produtivo, que "quer ajudar o aluno a entender o uso de sua língua materna de maneira mais eficiente." (TRAVAGLIA, p. 39, 2005).

No tocante à compreensão dos memes no âmbito da linguagem, defendemos que estes podem ser compreendidos como gêneros discursivos. Para Bakhtin (2003), os gêneros discursivos são "tipos relativamente estáveis de enunciado" que apresentam características básicas, como conteúdo temático, plano composicional e estilo. Assim, o gênero discursivo meme surge atrelado às formas de interação entre os sujeitos no contexto do virtual. Em relação às características, comumente apresenta: i) no plano composicional, estrutura com imagem e expressão linguística em caixa-alta, o que pode variar $^{1}$; ii) em relação ao conteúdo temático, assuntos que estão em ampla discussão na sociedade e que podem envolver problemáticas políticas, sociais, culturais etc.; iii) e, por fim, em relação ao estilo apresentam uma linguagem marcada por escolhas lexicais e fraseológicas dotadas de informalidade e com uso figurativo, com a finalidade de provocar humor, ironia e outros efeitos de sentido. 
Os memes têm tido uma grande expressividade devido às tecnologias e ao constante uso das redes sociais, que possibilitam a sua propagação. Esses textos estão, indissociavelmente, impregnados de conceptualizações, posicionamentos e visões de mundo sobre inúmeros assuntos. Conforme explica Martino (2014, p. 177), “imagens, sons, gestos, palavras, melodias, jeitos de se vestir e, até mesmo, elementos complexos como crenças ou rituais se disseminam pela sociedade na forma de memes". Devido ao impacto que provocam, principalmente, entre os jovens, e como circulam na sociedade, o trabalho com esses textos pode ser extremamente produtivo para o ensino de língua portuguesa.

Faz-se necessário discutir o conceito de análise linguística, uma vez que essa expressão gera muitas interpretações dicotômicas. Enquanto alguns a compreendem como o ensino descritivo da língua, "um conceito próprio do estudo científico da língua, a respeito de suas diversas unidades (o fonema, a palavra, o sintagma, a frase, o texto e o discurso), que se desenvolve com base em estudos descritivos de diversas tendências teóricas" (REINALDO, 2012, p. 230), outros a compreendem com "fins didáticos", ou seja, a compreendem como uma análise holística da língua. Debruçamo-nos, aqui, sobre este último conceito de análise linguística, o qual corresponde a uma análise "plena" da língua, que une as atividades epilinguísticas, de reflexão dos recursos do texto, efeitos de sentido das palavras etc., e metalinguísticas, que correspondem ao conhecimento da própria língua, "por meio de conceitos, classificações, entre outras operações" (REINALDO, 2014, p. 231).

Dessa maneira, quando nos referimos à análise linguística de textos multimodais estamos priorizando um tipo de análise que focaliza não somente as questões linguísticas, gramaticais, o saber da língua, mas também a reflexão sobre o uso da língua, a discussão dos efeitos de sentido dos elementos linguísticos, no plano da enunciação (REINALDO, 2014).

\section{O PERCURSO METODOLÓGICO}

Para realização deste estudo exploratório-descritivo, utilizou-se como aporte metodológico a pesquisa-ação educacional (TRIPP, 2005), a qual consiste em uma investigação que, ao tempo em que realiza o estudo, busca contribuir com ações para 
provocar mudanças na realidade do cotidiano pesquisado. Segundo Tripp (2005, p. 445), “a pesquisa-ação educacional é principalmente uma estratégia para o desenvolvimento de professores e pesquisadores de modo que eles possam utilizar suas pesquisas para aprimorar seu ensino e, em decorrência, o aprendizado de seus alunos".

Quanto aos procedimentos técnicos adotados para coleta de dados, empregou-se a observação participante (MARCONI; LAKATOS, 2017), com sistematização das aulas no relatório de Estágio Supervisionado II. Assim, o percurso metodológico consistiu nas seguintes etapas: 1) reconhecimento do perfil da turma; 2) planejamento das aulas com memes; 3) execução da proposta de ensino com memes na turma; 4) monitoramento dos efeitos da proposta e sistematização das observações a cada aula ministrada; 5) avaliação dos resultados.

A proposta de análise linguística a partir de memes foi construída e aplicada durante o ano de 2019, no período do Estágio Supervisionado II de Língua Portuguesa, o qual foi realizado no Colégio Estadual Odorico Tavares, em Salvador-BA, com uma turma do terceiro ano do ensino médio, composta de 25 estudantes. Para este artigo, selecionamos para a discussão três aulas ministradas. Objetivando proporcionar uma melhor definição do que é um meme, apresentamos as breves considerações a seguir.

O termo "memes" foi utilizado pela primeira vez em 1976, na obra $O$ gene egoísta, de Richard Dawkins (CHAGAS, 2020). Naquela época, ainda não havia a internet e as redes sociais. Por isso, Dawkins utilizou o termo, primariamente, para fazer uma analogia: para o autor, assim como o gene transmite uma informação genética, o "meme" transmite uma informação cultural (SHIFMAN, 2020). Sob essa ótica, os memes seriam como os "genes" da cultura, ou seja, são replicadores e transmissores de ideias culturais, crenças e valores (RODRIGUES, 2018).

Com o passar do tempo e com o surgimento da era digital, sobretudo a partir da WEB 2.0, em 2004, com o surgimento das plataformas Orkut, Twitter, Facebook etc., este termo passou a ser vinculado a qualquer ideia, som, texto, imagem, desenho, palavra, crença, gesto, que é replicado, transformado e transmitido culturalmente (MARTINO, 2014). Aqui, chamamos atenção em especial para os memes que são veiculados em redes sociais na forma de textos multimodais, ou seja, veiculados com imagens, palavras, cores, sons, e os consideramos enquanto gêneros discursivos, conforme já explicitado. 
Exposta a metodologia e os procedimentos empregados, detalhamos, na próxima seção, a aplicação da proposta na sala de aula.

\section{RELATO DA PROPOSTA COM MEMES E ANÁLISE LINGUÍSTICA NO COLÉGIO ESTADUAL ODORICO TAVARES}

Durante o período de Estágio Supervisionado II de língua portuguesa, a docente do colégio nos solicitou o ensino do conteúdo figuras de linguagem para uma turma do terceiro ano do Ensino Médio, composta por 25 estudantes. Em um primeiro contato com os discentes, fizemos uma leitura do perfil da turma e constatamos o predominante uso dos celulares nas aulas. Tratava-se de estudantes que se comunicavam, frequentemente, por meio dos smartphones, portanto, mantinham um forte vínculo com a tecnologia. Identificada essa questão, elaboramos o conteúdo de língua portuguesa com memes, com o objetivo de estimular o interesse destes nas aulas, bem como de promover a aprendizagem do conteúdo por meio dos usos da linguagem.

Após essa etapa diagnóstica, iniciamos a elaboração da proposta. Para isso, coletamos memes da internet e de diversas redes sociais, tais como Instagram, Facebook e Google. Também confeccionamos memes em sites geradores de memes, como o www.gerarmemes.com.br. Nesse processo, construímos a maioria dos memes com a temática da violência de gênero, trazendo pautas como o machismo e o feminicídio, tendo em vista que esses assuntos merecem urgente debate na escola.

A partir dessa perspectiva, buscamos, com os memes, incentivar a análise linguística, trabalhando com as questões discursivas e gramaticais e não apenas tratando o texto como um objeto pronto e acabado (MARCUSCHI, 1996). Dessa forma, após a elaboração da proposta e dos planos de aula, procedemos à terceira etapa deste estudo, a aplicação de uma atividade com memes, com o objetivo de sondar o conhecimento dos estudantes em relação à temática da violência de gênero, bem como em relação à leitura e análise linguística de textos multimodais.

\section{Aula 01}


A atividade consistia em dividir a sala em seis grupos. Cada grupo receberia um meme, o qual tinha por temática: assédio sexual, feminicídio, machismo, sexismo, dentre outras temáticas. Esperava-se que os grupos fossem capazes de:

1) Apresentar análise interpretativa do meme, comentando os aspectos composicionais e linguísticos, tais como: temática, uso dos símbolos, imagens, cores etc., utilizados para a construção do sentido, bem como comentando as questões linguísticas, escolhas lexicais, construções fraseológicas, disposição dos elementos no meme, e outras questões;

2) Relacionar o meme com um acontecimento atual que tenham presenciado, vivido ou lido;

3) Entregar a sistematização da análise linguística do meme por escrito.

Todavia, no momento da exposição, notamos que muitos estudantes não comentaram os aspectos linguísticos do texto, tanto verbais quanto não verbais. Com base em seus conhecimentos de mundo, eles apenas expuseram a temática do meme de forma superficial, sem ir além e sem explorar as possibilidades verbo-imagéticas. É importante chamar atenção para o fato de que estávamos ministrando as aulas para uma turma de terceiro ano de Ensino Médio, da qual esperávamos maior maturidade na discussão e interpretação de textos multimodais. Entretanto, não foi isso que foi observado entre os pré-vestibulandos. Para discussão dessa questão, expomos, a seguir, um meme utilizado durante o trabalho em grupo:

Figura 01 - "Xô embuste"

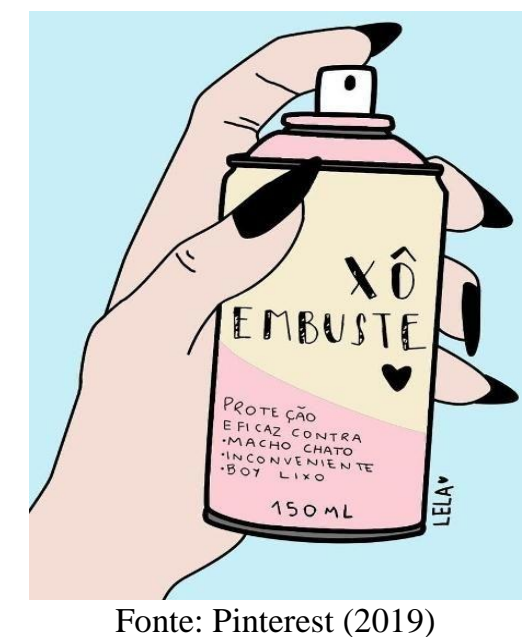


Após a figura do meme ser entregue, fomos chamadas para oferecer explicação por uma equipe que se encontrava com bastante dúvida. Mesmo após a segunda explicação detalhada da atividade, os alunos nos chamaram:

Aluno A: Não entendi o que é para fazer, professora.

Professora: Vocês devem analisar, interpretar esse meme com base nos elementos que ele dispõe. Qual a temática vocês acham que está aí presente?

Aluno A: Não sei. Eu não estou entendendo bem.

Professora: $\mathrm{O}$ que vocês veem na imagem?

Aluno B: Ah, a mão de uma mulher, né!

Professora: E o que diz o texto escrito?

Aluno A: "Xô, embuste", mas eu não sei como dizer o que é a temática. É a propaganda de um novo produto. Acho que é um desodorante.

Professora: E você sabe o que é embuste?

Aluno A: Ah eu sei né, claro, é uma pessoa chata, que fica enchendo o saco.

Professora: Certo. E qual o efeito de sentido dessa palavra para o texto?

Diante das falas, vemos a dificuldade de os alunos interpretarem o meme, mesmo sendo um texto de ampla circulação e com uma linguagem presente na realidade deles. Também podemos perceber a dificuldade de identificarem a ironia do texto, pois o Aluno A acreditou, de fato, que o meme da Figura 01 era um anúncio publicitário apresentando um produto, como um desodorante, e não uma situação hipotética construída para trazer a temática do assédio contra as mulheres na sociedade. Tendo em vista esses obstáculos enfrentados pelos alunos, houve a necessidade de continuarmos com as indagações, guiando-os no processo de análise linguística do referido texto.

Professora: E por que a mulher precisaria usar esse "spray"? Contra quem ela usaria? Quem seria esse embuste? O que está escrito na recomendação do spray?

Aluno C: Ah, ela usa contra um homem chato.

Professora: Por que chato? O que esse homem poderia estar fazendo a ela a ponto de ela IMAGINAR utilizar um spray contra ele?

Aluno C: Não sei...soltando piadas, perseguindo essa mulher na rua...

Professora: Então qual seria o tema desse meme? Existe algum acontecimento atual que vocês possam relacionar com ele? 
Esse mesmo processo de atendimento foi feito em diversos grupos. Após a socialização, notamos que poucos estudantes exploraram o texto verbal, os desenhos, as cores do meme em suas falas, o efeito de sentido das palavras, a disposição dos elementos, as escolhas lexicais. Com isso, constatamos que a turma realmente necessitava de uma proposta de ensino que tivesse como pauta os textos multissemióticos como os memes, pois todos hesitavam e apresentavam dúvida na leitura de textos que envolviam múltiplas semioses, processo esse fundamental e explícito nas habilidades de Linguagens e Tecnologias da BNCC (BRASIL, p. 483) para o Ensino Médio, das quais destacamos:

(EM13LGG103) Analisar, de maneira cada vez mais aprofundada, o funcionamento das linguagens, para interpretar e produzir criticamente discursos em textos de diversas semioses.

(EM13LGG104) Utilizar as diferentes linguagens, levando em conta seus funcionamentos, para a compreensão e produção de textos e discursos em diversos campos de atuação social.

\section{Aula 02}

Logo, dando continuidade e visando trabalhar com essas habilidades, projetamos na aula seguinte à relatada um por um os memes de cada equipe e fomos construindo, juntos, a análise linguística; falamos sobre a necessidade de olhar para todos os aspectos do texto, de comentá-los e explorá-los, pois eles também constituíam informações fundamentais para a sua compreensão; trouxemos a importância de, por exemplo, em uma questão discursiva, comentar os aspectos textuais, linguísticos, não apenas trazer o seu conhecimento de mundo sobre a temática; comentamos a importância de perceber os detalhes do texto multimodal, tais como cores, efeitos de sentido das palavras, imagens, formas etc., organização da estrutura; também explicamos, nessa aula, o conceito de texto multimodal, o qual parecia ser desconhecido pelos discentes.

\section{Aula 03}

Após esse primeiro contato com o processo de análise linguística a partir dos memes, colocamos em prática o ensino do conteúdo figuras de linguagem com esses textos. Inicialmente, mostrávamos a imagem e questionávamos aos estudantes: "qual figura de linguagem vocês identificam nesse texto? O que nós podemos interpretar? Qual a importância da imagem? E dessa cor? E dessa determinada palavra? Como os elementos foram dispostos no meme para a construção de sentido?" 
Durante essa aula notamos que os estudantes já estavam se familiarizando com a interpretação dos memes, pois já apresentavam suas compreensões sobre os textos, participando mais ativamente das discussões. A seguir, apresentamos três memes, dois produzidos por nós (Figuras 02 e 03) e um coletado da internet (Figura 04), os quais foram utilizados para o ensino das figuras de linguagem gradação, hipérbole e ironia, respectivamente:

Figura 02 - Figura de linguagem: Gradação

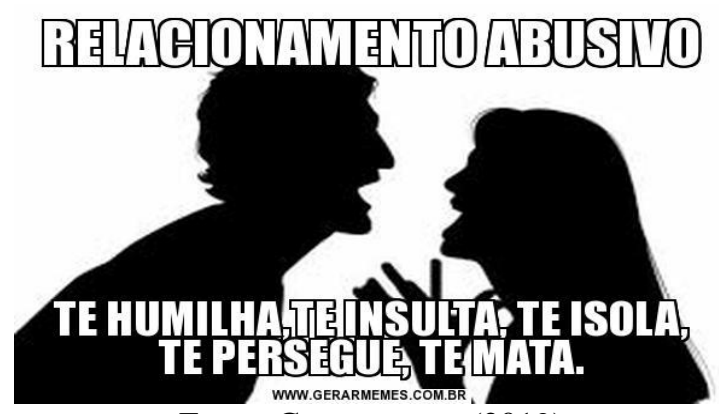

Fonte: Gerar memes (2019).

Figura 03 - Figura de linguagem: hipérbole

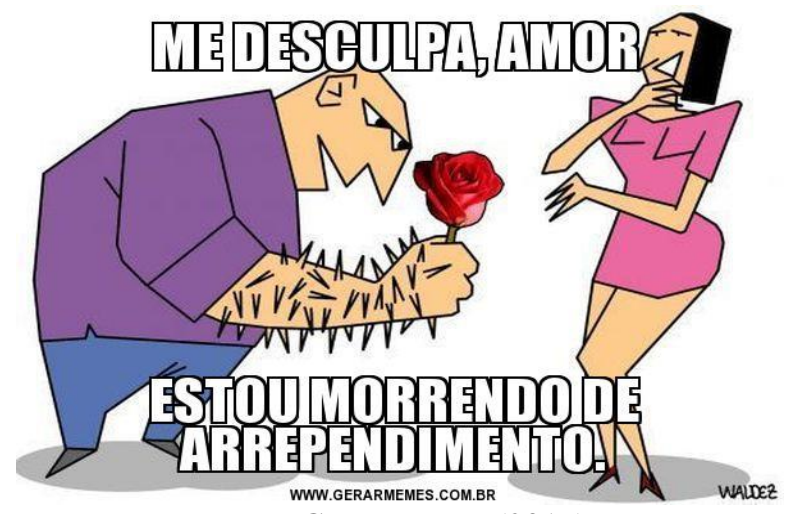

Fonte: Gerar memes (2019).

Figura 04 - Figura de linguagem: ironia

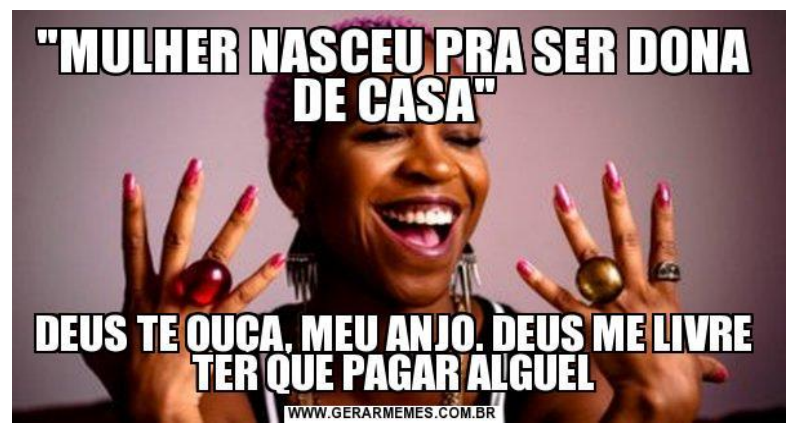

Fonte: Gerar memes (2019). 
Essa foi a aula em que houve maior participação e interação da turma. No encontro, eles se mostraram atentos e se identificaram, muitas vezes, com a linguagem ou as pessoas utilizadas para compor o meme. Um exemplo interessante pôde ser notado quando utilizamos o meme que tem a imagem da cantora Karol Conká (Figura 04), pois houve um processo de identificação das meninas com a temática e a referida cantora, o que as levou a emitir opiniões, interagir e debater amplamente o assunto. Isso demonstrou a relevância de ministrar os conteúdos com base em textos e conhecimentos da realidade dos estudantes, visto que essa prática proporciona estímulo, referência e identificação no processo de aprendizagem.

Destarte, findamos essa experiência de ensino com a certeza de que impactamos positivamente a vida acadêmica dos discentes, que desenvolveram habilidades tão necessárias como a interpretação crítica, o olhar atento para os textos de múltiplas semioses.

\section{CONSIDERAÇÕES FINAIS: REFLEXÕES E CONTRIBUIÇÕES PARA O ENSINO DE LÍNGUA PORTUGUESA}

Tendo em vista as mudanças nos modos de ser, aprender, de se comunicar e de se relacionar no mundo globalizado e interconectado, percebemos a necessidade de trazer para os alunos da escola pública uma proposta de ensino que contemplasse um gênero do mundo digital: o meme. Esse projeto tornou-se ainda mais fundamental no decorrer do processo, quando percebemos que os estudantes, apesar de lidarem corriqueiramente com os memes e de serem ativos no tocante à interação nas redes sociais, não desenvolviam uma leitura crítica desses textos e não estavam acostumados a vê-los no ensino de língua portuguesa, como textos legítimos das práticas de linguagem.

Quando indagados sobre o conteúdo dos memes, na sala de aula, pareciam não saber realizar o link entre as questões linguísticas e temáticas, fator proporcionado pelo processo de análise linguística. A percepção dessa questão nos causou, a princípio, estranhamento, uma vez que pensamos que a proposta seria realizada sem dificuldades. No entanto, levantamos a hipótese de que, por não estarem acostumados ao ensino de língua portuguesa vinculado aos gêneros digitais, os discentes possam ter tido 
dificuldade de reconhecê-los não apenas enquanto textos "divertidos" que circulam em seus smartphones, mas como, de fato, textos marcadamente produzidos e constituídos pela e na linguagem e, por isso, impregnados de intencionalidades, sentidos e construções linguísticas.

Com essa experiência, chegamos à resposta que se pretendia investigar nesta pesquisa-ação: em realidade, os alunos tinham uma defasagem no tocante à análise linguística de memes - e de textos multimodais em geral -, apesar de estarem imersos em espaços virtuais de interação, vendo-os a todo momento, manipulando-os, e isso se deve ao fato de esses gêneros digitais não serem inseridos na perspectiva educacional, sob a ótica do ensino de língua portuguesa, o que, por conseguinte, ocasionou os obstáculos enfrentados no decurso do projeto, já que estavam aprendendo outros letramentos, estavam enxergando memes e não apenas vendo-os. Outras pesquisas e estudos, no entanto, são fundamentais para compreendermos os desdobramentos dessa proposta.

Assim, constatamos a importância de os professores de língua portuguesa inserirem em suas práticas a cultura do digital, sobretudo por meio dos novos gêneros desse meio, para que formemos alunos multiletrados capazes de "explorar e perceber os modos como as diversas linguagens se combinam de maneira híbrida em textos complexos e multissemióticos, para ampliar suas possibilidades de aprender, de atuar socialmente e de explicar e interpretar criticamente os atos de linguagem." (BRASIL, 2018, p. 483).

\section{Referências}

BAKHTIN, Mikhail. Os gêneros do discurso. In: BAKHTIN, Mikhail. Estética da criação verbal. São Paulo: Martins Fontes, 2003. p. 262-306.

BRASIL. Ministério da Educação. Base nacional comum curricular: ensino médio. Brasília, DF, [2018]. Disponível em: http://portal.mec.gov.br/docman/abril-2018pdf/85121-bncc-ensino-medio/file. Acesso em: 24 abr. 2019.

CHAGAS, Viktor. Da memética aos estudos sobre memes: uma revisão da literature concernente ao campo nas últimas cinco décadas (1976-2019). In: CHAGAS, Viktor (org.). A cultura dos memes: aspectos sociológicos e dimensões políticas de um fenômeno do mundo digital. Salvador: EDUFBA, 2020. p. 23-78. 
DAWKINS, Richard. O gene egoísta. Belo Horizonte: Itatiaia; São Paulo: Universidade de São Paulo, 1979.

FERREIRA, Helena Maria; VILLART-NEDER, Marco Antônio; COE, Geanne dos Santos Cabral. Memes em sala de aula: possibilidades para a leitura das múltiplas semioses. Periferia, Rio de Janeiro, v. 11, n. 11, p. 114-139, 2019. DOI: https://doi.org/10.12957/periferia.2019.36936.

GERALDI, João Wanderley. Concepções de linguagem e ensino de português. In: GERALDI, João Wanderley; ALMEIDA, Milton José de (org.). O texto na sala de aula. 3. ed. São Paulo: Ática, 2002. p. 39-46.

GERAR MEMES. Gerar Memes. [S. l., 2019]. Disponível em: https://www.gerarmemes.com.br/. Acesso em: 14 abr. 2019.

KNOBEL, Michele; LANKSHEAR, Colin. Memes on-line, afinidades e produção cultural. Traduzido por Viktor Chagas. In: CHAGAS, Viktor (org.). A cultura dos memes: aspectos sociológicos e dimensões políticas de um fenômeno do mundo digital. Salvador: EDUFBA, 2020. p. 85-125.

LEMKE, Jay L. Letramento metamidiático: transformando significados e mídias. Trabalhos em Linguística Aplicada, Campinas, v. 49, n. 2, p. 455-479, jul./dez. 2010.

LEVY, Pierre. Cibercultura. Tradução de Carlos Irineu da Costa. São Paulo: Ed. 34, 1999. Disponível em:

https://mundonativodigital.files.wordpress.com/2016/03/cibercultura-pierre-levy.pdf. Acesso em: 14 abr. 2019.

MARCONI, Marina de Andrade; LAKATOS, Eva Maria. Fundamentos de metodologia científica. 8. ed. São Paulo, SP: Atlas, 2017.

MARCUSCHI, Luiz Antônio. Exercícios de compreensão ou copiação nos manuais de ensino de língua? Em Aberto, Brasília, DF, ano 16, n. 69, jan./mar. 1996.

MARTINO, Luís Mauro Sá. Teoria das mídias digitais: linguagens, ambientes e redes. 2. ed. Petrópolis: Vozes, 2014.

RECUERO, Raquel da Cunha. Memes em webblogs: proposta de uma taxonomia. Revista FAMECOS, Porto Alegre, n. 32, p. 23-31, abr. 2007.

REINALDO, Maria Augusta G. de M. O conceito de análise linguística como eixo de ensino de língua portuguesa no Brasil. Estudos linguísticos/Linguistics Studies, Lisboa, n. 8, p. 229-241, 2012.

RODRIGUES, Marina Roale Fabrício. "Meme, meu idioma”: os usos e apropriações de memes por nativos digitais para falar de política no cotidiano. 2018. Dissertação (Mestrado em Comunicação Social) - Universidade Federal Fluminense, Rio de 
Janeiro,

2018.

Disponível

em: https://app.uff.br/riuff/bitstream/1/11327/1/Marina\%20Roale_Disserta\%C3\%A7\%C3\% A3o\%20Final2018.pdf. Acesso em: 14. ago. 2019.

ROJO, Roxane H. Pedagogia dos multiletramentos. In: ROJO, Roxane H.; MOURA, Eduardo. Multiletramentos na escola. 2. ed. São Paulo: Parábola Editorial, 2016. p. 2045 .

SHIFMAN, Limor. Uma biografia telegráfica de um encrenqueiro conceitual. Traduzido por Viktor Chagas. In: CHAGAS, Viktor. A cultura dos memes: aspectos sociológicos e dimensões políticas de um fenômeno do mundo digital. Salvador: EDUFBA, 2020. p. 79-83.

SOARES, Magda. Novas práticas de leitura e escrita: letramento na cibercultura. Revista Educação \& Sociedade, Campinas, v. 23, n. 81, p. 143-160, 2002.

TRAVAGLIA, Luís Carlos. Gramática e interação: uma proposta para o ensino de gramática. 10. ed. São Paulo: Cortez, 2005.

TRIPP, David. Pesquisa-ação: uma introdução metodológica. Tradução de Lólio Lourenço de Oliveira. Educação e Pesquisa, São Paulo, v. 31, n. 3, p.443-466, set./dez. 2005.

Recebido em: 01/09/2020

Aceito em: 01/12/2020

\footnotetext{
${ }^{1}$ Recuero (2007) propõe uma taxonomia a respeito dos diversos tipos de memes encontrados na internet.
} 